\title{
The Role of Stakeholders on Successful of Tourism Event Rendang Journey Culinary Event in Indonesia
}

\author{
Ulfi Maranisya* \\ National University \\ *ulfimaranisya1603@gmail.com
}

\begin{abstract}
This event was carried out before the Covid 19 pandemic. This research was conducted to provide education and applications that an event concept can be used as the knowledge that can educate the public. In addition, the purpose of this research has not been found with the concept of a similar event with the same target and results as the successful event of the Rendang Journey. Today, MICE (Meeting, Incentive, Convention, Exhibition) is an industry that can drive a generator of economic growth. The growth of the meetings and conventions industry has been stimulated by the growth of the knowledge economy. Planning an event can't be done in a short amount of time. Preparation of an event with the concept ofmature and well-directed will produce a successful event. Rendang Journey is a Culinary Tourism for culture, with youth generation as the target, and three serial activities, Seminar \& Talkshow, Creations of Rendang Cooking Competition, and Culinary Tours to West Sumatera. The research methodology uses a mixed qualitative approach and quantitative (mixed methods) case studies to see the role and contribution of culinary tourism events to tourism policy. Data were collected using questionnaires and interviews as supporting data and confirmation to respondents.
\end{abstract}

Keywords: Culinary Tourism, Rendang, Tourism Stakeholders 
The Role of Stakeholders on Successful of Tourism Event

Rendang Journey Culinary Event in Indonesia

\section{A. Introduction}

Indonesia is one of the destinations for the MICE Industry (Meetings, Incentives, Conventions, and Exhibitions. Meeting activities are organized activities with the aim of participants to socialize, discuss a particular topic appointed, exhibition activities are not available at the seminar. Incentives or usually also known as incentive travel activities are gifts in the form of trips given by the company to employees to stimulate productivity. The convention is an organized activity with the aim of participants to socialize, discuss a certain topic raised, secondary exhibition activities are available at the convention activity. The exhibition where the main activity or activity of participants visiting the exhibition directly, the main focus of cooperation in sales (business to business/B2B).

In exhibition activities, products and product promotion tools are presented by the sales marketing and public relations department. MICE Industry activities play an important role in increasing the number of foreign tourist arrivals to Indonesia. MICE business activities have opened up new job opportunities. It has not only created a seasonal workforce but has also created permanent jobs for people who have abilities that are no different from tourism businesses in developing countries. MICE are businesses that have a less negative impact on the environment than tourism businesses that bring in a lot of people (mass tourism). MICE focuses on the number of participants who are not too many so that the use of transportation will be reduced so that it will reduce congestion and pollution caused (Fenich, 2012).

The Ministry of Tourism and Creative Economy of Indonesia has made MICE or Event tourism one of the 7 special interest tours that will be the focus of development. For optimal development, the Ministry of Tourism and Creative Economy established the Directorate of Promotion of Conventions, Incentives, Events, and Special Interests under the Directorate General of Tourism Marketing. Meanwhile, the Directorate of Special Interest Tourism Development, Conventions, Incentives, and Exhibitions is under the Directorate General of Tourism Destination Development. The purpose of holding meetings, incentives, conventions, and exhibitions (Sultana, 2018), both privately and publicly, people feel the need to mark important events in their lives, as well as to celebrate important moments. An event is a consciously planned event with good and clear preparation that can achieve a certain goal (Getz \& Page, 2016). Planning an event cannot be done in a short enough time. Preparation of an event with a mature and well-directed concept will result in a successful event. An event is a unique moment that is celebrated with ceremonies and rituals for a specific purpose. A tourism event and stakeholders are closely related (McCartney, 2010).

Stakeholders at an event are people who are directly involved with the event. Their level of influence on an event depends on several factors and motives, such as personal motives, power, and authority, resources, and level of involvement. 9 points for assessment, namely Motivation, Planning, Patterns \& 
The Role of Stakeholders on Successful of Tourism Event

Rendang Journey Culinary Event in Indonesia

Processes, Temporal, Policy, Knowledge Creation, Outcomes, Economic Outcomes, Social Cultural Political. The focus of the indicators applied to the research is only 5 points, namely Motivations, Planning, Patterns \& Processes, Knowledge Creation, Outcomes (Getz \& Page, 2016). Planning starts from the beginning by conceptualizing the Rendang Journey culinary tourism event. Patterns \& Processes are carried out while collaborating with stakeholders for Rendang Journey culinary tourism event. The development of science resulted from experiences during the event as well as the addition of new knowledge gained. The results are the achievements obtained during the implementation of the Rendang Journey culinary tourism event.

\section{B. Literature Review}

\section{Motivation}

Motivation is a driving force from within a person's heart to do or achieve a goal. Motivation can also be said as a plan or desire to achieve success and avoid failure. In other words, motivation is a process to achieve a goal (Joseph, 2015). All humans have basic needs, in 5 levels in the shape of a pyramid, people start pushing from the lowest level. These five levels of needs are known as Maslow's hierarchy of needs, ranging from basic biological needs to more complex psychological motives, which only become important after basic needs are met (Taormina \& Gao, 2013). Needs at one level must be met at least partially, before the needs at the next level become the determinant of important action. There are various motivations for someone is doing something (Getz \& Page, 2016).

Building the best motivation for a tourism event will directly affect the number of participants or visitors to the event. The opinion above is clear that studying a tourism event and motivation is a monitor for an event organizer to see or understand the satisfaction of stakeholders and participants in an event. The goal is good to see the success of the events being held, and in the long term to know the satisfaction of the participants. In addition, this statement aims to briefly review motivational research related to tourism. It is believed that such efforts will help identify existing theoretical and methodological problems, and clarify the direction of further research (Akgunduz \& Yesim, 1995).

\section{Planning}

Attention to stakeholders on event management, partnership, and collaboration can be that events are one of the common products developed by conventions that are oriented towards the activities of their members (Pernecky, 2015). Planning for organizing an event must be planned. The choice of place, concept, and rules of event will be able to influence the process of success of an event. Designing an event must be well conceptualized and have a main purpose. Here are some steps that should be taken in conceptualizing an event (Kaiser,

Tourism Research Journal, Volume 5 (2), 2021 
The Role of Stakeholders on Successful of Tourism Event

Rendang Journey Culinary Event in Indonesia

2019) includes Setting Up adopting a strategic framework that will guide the planning process, and develop a mission statement that motivates the entire plan.

Analyzing collects data and conducts external and internal analyzes that reveal key strategic issues to be addressed in the plan. Strategizing develops the artistic, administrative, and financial strategies that have the highest probability of achieving the organization's mission. So, it can be concluded that developing a strategic plan for the Rendang Journey culinary tourism event can be carried out in three stages, namely preparing well, analyzing, and determining the right strategy for achieving the vision and mission of the culinary tourism event.

\section{Patterns \& Processes}

Patterns and processes can be defined as a series of tourism events, which can be assessed and seen from the life cycle of a tourism event (event life cycle). Goes through the initial stages of introduction, growth, maturity, and possible decline. The tourism event cycle has limitations because it cannot predict time or income (McCartney, 2010). Patterns and processes can be more easily understood by dividing them into several terms, processes which mean the steps followed to achieve a tourism event goal, and patterns which mean repetition of the same basic features or rules during the event life cycle of a process. It is also important to take into account clear distinguishing factors, such as cultural peculiarities, exact date, and time. Patterns are generated from the process. In other words, the study of patterns must be free from any assumptions about the process.

\section{Knowledge Creation}

Sometimes problems must also be a concern in the formation and development of tourism events to minimize the shortcomings and limitations of the mindset in innovating (Giampiccoli \& Saayman, 2018). Knowledge consists of truths and beliefs, perspectives and concepts, methodological judgments and expectations, and know-how. Knowledge is a flowing mix of framed experiences, values, contextual information, and expert insights that provide a framework for evaluating and incorporating new experiences and information (Mohajan, 2017). They all originate and apply in the minds of those who know. In organizations, it is often applied, not only in documents or repositories but also in organizational routines, processes, practices, and norms.

\section{Outcomes}

Tourism plays an important role in the economic, social, and cultural development of many countries. Global tourism provided nearly US\$1.5 trillion in tourism expenditure and reached 1.5 billion tourist arrivals in 2019. Positive outcomes of tourism include economic benefits such as tax revenue, job creation, or diversification of the local economy (UNWTO, 2020). Because it is dynamic, every tourism activity will develop, adapt and change from time to time, influenced

Tourism Research Journal, Volume 5 (2), 2021 
The Role of Stakeholders on Successful of Tourism Event

Rendang Journey Culinary Event in Indonesia

by external and internal factors. The adjustment and impact of changes that occur in tourism activities cannot be predicted and avoided.

The same concept and experience every year in tourism activities or events will be a problem because the concept can become stale and reduce the interest of participants or visitors who come. External factors that can affect interest, the level of participant visits to tourism events are increasingly fierce competition against similar tourism activities (McCartney, 2010). Some solutions that can be done are re-studying the planning of an event, the use of resources, innovative thinking strategies, and promotion and marketing strategies for tourism events.

\section{Stakeholders}

Stakeholders in the form of any group or individual who can influence or be influenced by the achievement of a company's goals, adds that the stakeholder theory emphasizes the interaction of power, legitimacy, and urgency (Wogu, 2016). The role of stakeholders in the implementation of a tourism event is very important, therefore there are 4 key stakeholders namely growing, developing, maintaining, or leaving which are choices related to investing in a relationship (Rachmawati \& Fountain, 2020). Stakeholders are people or groups who can influence the organization. Organizational stakeholders are categorized as groups that have an interest and can influence an organization in achieving its goals.

Policy stakeholder analysis is a process to provide insight into, and understanding of, the interactions between tourism project activities and stakeholder interests (Wang \& Aenis, 2019). That some people have the cognitive ability to directly solve problems related to stakeholders. The analysis of stakeholders is based on the belief that there is a reciprocal relationship between organizations and certain groups and individuals. These groups or groups of individuals are categorized as policymakers because they have the right or power to do something decisions.

The transfer of concepts and significant changes in the composition of the fulfillment of needs and the balance of meeting the needs and interests of each policyholder. The media is one of the important policymakers in the culinary tourism event of the Rendang Journey. The media has four functions, namely: Surveillance, this is related to the function of the media in terms of reporting, providing information to the public, and warning them of what is happening in the surrounding environment, both at home and abroad. Interpretation relates to the function of the media in interpreting, providing theoretical views and opinions on events and trends in society. The editorial page which is generally found in every print media is one example. Socialization (values transmission), is one of the important functions of the media, namely as a channel of ideas between generations.

The media can disseminate dynamic policies and knowledge from time to time. Entertainment, with the media the public can get entertainment such as 
The Role of Stakeholders on Successful of Tourism Event

Rendang Journey Culinary Event in Indonesia

listening to music through the radio, watching entertainment shows through television and internet networks, reading information about lifestyle, sports, and so on in print media such as magazines, tabloids, and newspapers (Straubhaar \& Larose, 2004). The media has various forms of broadcasting, print, and internet networks. Traditionally, the media are the gatekeepers of information. The presence of the internet network has created an easy source of information rather than just relying on journalistic reporting. Websites and blogs can be created using the internet network, while traditional television news channels now facilitate websites that allow viewers to access anytime and anywhere. Information via television, radio, and the internet remains a strong factor in creating awareness of the destination and the program, and can influence the audience's intention to watch or not. Media management was formed to increase and create high awareness about the event and its objectives. Understand the goals, and the people who support the event such as sponsors, government, local communities, and associations (McCartney, 2010).

\section{Research Methodology}

This research uses a mixed qualitative and quantitative approach (mix method) case study to see the extent to which the role and positive contribution of Rendang Journey's culinary tourism event to tourism policy. Data collection was carried out using questionnaires and interviews as supporting data and confirmation to respondents. Interviews were conducted after the implementation of the Rendang Journey culinary tourism event which was carried out in two provinces, DKI Jakarta and West Sumatra.

The respondents of this study were twenty tourism stakeholders, some of whom were Mrs. Mutia Hatta, Mrs. Mufidah Jusuf Kalla, Mr. Fasli Jalal, Mr. Achyaruddin from the Director-General of Destination Development and MICE of the Ministry of Tourism and Creative Economy, Mr. William Wongso, and Chef Vindex Tengker as Indonesia Culinary Expert, Mr. Jacky Mussry as Vice President of Markplus Inc and Mrs. Yoseptin Pratiwi as Managing Editor of Femina Magazine. Interesting theme and inspiration for young people to love Indonesian culinary.

Data collection techniques were carried out by distributing questionnaires. The questions gave or questionnaires that have been provided to respondents relate to the effects of the Rendang Journey culinary tourism event on national tourism policies. The questionnaire given to the respondent is closed in the sense that it expects a short question or chooses the available answer options. Interviews are a method of collecting data orally and directly, which were carried out before the Covid 19 pandemic in Indonesia. 
The Role of Stakeholders on Successful of Tourism Event

Rendang Journey Culinary Event in Indonesia

\section{Result}

Table 1. Respondents

\begin{tabular}{llrrr}
\hline & Frekuensi & $\begin{array}{c}\text { Valid } \\
\text { Percent }\end{array}$ & $\begin{array}{c}\text { Cumulative } \\
\text { Percent }\end{array}$ \\
\hline Gender & & & & \\
Valid & Man & 11 & 55.0 & 55.0 \\
\cline { 2 - 5 } & Woman & 9 & 45.0 & 100.0 \\
\cline { 2 - 5 } & Total & 20 & 100.0 & \\
\hline
\end{tabular}

\begin{tabular}{|c|c|c|c|c|}
\hline \multicolumn{5}{|l|}{ Age } \\
\hline \multirow[t]{5}{*}{ Valid } & $<28$ year & 1 & 5.0 & 5.0 \\
\hline & $29-39$ year & 10 & 50.0 & 55.0 \\
\hline & $40-50$ year & 7 & 35.0 & 90.0 \\
\hline & $>50$ year & 2 & 10.0 & 100.0 \\
\hline & Total & 20 & 100.0 & \\
\hline \multicolumn{5}{|c|}{ Hobby } \\
\hline \multirow[t]{5}{*}{ Valid } & Traveling & 6 & 30.0 & 30.0 \\
\hline & Photography & 6 & 30.0 & 60.0 \\
\hline & Cooking & 6 & 30.0 & 90.0 \\
\hline & And other & 2 & 10.0 & 100.0 \\
\hline & Total & 20 & 100.0 & \\
\hline
\end{tabular}

Source: Data processed (2021)

Twenty respondents from stakeholders of Tourism Event Rendang Journey Culinary Event in Indonesia. The majority of respondents were women (55\%). 50\% they are $29-39$ age. $40 \%$ of them have hobbies traveling, and each has the same value $(30 \%)$. For the types of companies that support this event, namely television \& online media, and government.

Table 2. Validity Test

\begin{tabular}{lccc}
\hline \multicolumn{1}{c}{ Variable } & $\begin{array}{c}\text { Item } \\
\text { Statement }\end{array}$ & r-statistic & r-table \\
\hline Motivation & $\mathrm{X} 1.1$ & 0.846 & 0.444 \\
\cline { 2 - 4 } & $\mathrm{X} 1.2$ & 0.906 & 0.444 \\
\hline Planning & $\mathrm{X} 2.1$ & 0.818 & 0.444 \\
\hline Pattern \& Process & $\mathrm{X} 3.1$ & 0.739 & 0.444 \\
\cline { 2 - 4 } & $\mathrm{X} 3.2$ & 0.754 & 0.444 \\
\cline { 2 - 4 } & $\mathrm{X} 3.3$ & 0.754 & 0.444 \\
\hline Knowledge Creation & $\mathrm{X} 4.1$ & 0.744 & 0.444 \\
\cline { 2 - 4 } & $\mathrm{X} 4.2$ & 0.769 & 0.444 \\
\hline Outcomes & $\mathrm{Y} .1$ & 0.667 & 0.444 \\
\cline { 2 - 4 } & $\mathrm{Y} .2$ & 0.682 & 0.444 \\
\hline
\end{tabular}

Source: Data processed (2021)

Tourism Research Journal, Volume 5 (2), 2021 
The Role of Stakeholders on Successful of Tourism Event

Rendang Journey Culinary Event in Indonesia

Based on the table above, it shows that all questions for all variables are valid because the value of r-statistics $>$ r-table is 0.444 .

Table 3. Reliability Test

\begin{tabular}{lccc}
\hline \multicolumn{1}{c}{ Variable } & $\begin{array}{c}\text { Item } \\
\text { Statement }\end{array}$ & $\begin{array}{c}\text { Cronbach's } \\
\text { Alpha }\end{array}$ & $\begin{array}{c}\text { Alpha } \\
\text { Value }\end{array}$ \\
\hline Motivation & $\mathrm{X} 1$ & 0.613 & 0.60 \\
\hline Planning & $\mathrm{X} 2$ & 0.677 & 0.60 \\
\hline Pattern \& Process & $\mathrm{X} 3$ & 0.628 & 0.60 \\
\hline Knowledge Creation & $\mathrm{X} 4$ & 0.715 & 0.60 \\
\hline Outcomes & $\mathrm{Y}$ & 0.777 & 0.60 \\
\hline Source: Data processed (2021) & &
\end{tabular}

Based on the table above, shows that all variables are declared reliable because they have Cronbach's alpha value $>$ alpha value, which is 0.600.

Table 4. Determination Coefficient

\begin{tabular}{crrr}
\hline $\mathrm{R}$ & $\begin{array}{c}\mathrm{R} \\
\text { Square }\end{array}$ & $\begin{array}{c}\text { Adjusted } \\
\mathrm{R} \text { Square }\end{array}$ & $\begin{array}{c}\text { Std. Error of } \\
\text { the } \\
\text { Estimate }\end{array}$ \\
\hline $.686^{\mathrm{a}}$ & .470 & .329 & 1.07226
\end{tabular}

Source: Data processed (2021)

Based on the table above, the coefficient of determination is $47 \%$. This means that the outcome variable is influenced by the variables of motivation, planning, patterns \& processes, and the creation of knowledge by $47 \%$. While the remaining $53 \%$ is influenced by other variables that have not been studied.

Table 5. T-Test

\begin{tabular}{|c|c|c|c|c|c|}
\hline \multirow[t]{2}{*}{ Model } & \multicolumn{2}{|c|}{$\begin{array}{l}\text { Unstandardized } \\
\text { Coefficients }\end{array}$} & \multirow{2}{*}{$\begin{array}{c}\text { Standardized } \\
\text { Coefficients } \\
\text { Beta }\end{array}$} & \multirow[t]{2}{*}{$\mathrm{t}$} & \multirow[t]{2}{*}{ Sig. } \\
\hline & $\mathrm{B}$ & Std. Error & & & \\
\hline (Constant) & 5.849 & 4.101 & & 1.426 & .174 \\
\hline Motivation & .646 & .363 & .392 & 1.781 & .095 \\
\hline Planning & .371 & .387 & .214 & .959 & .353 \\
\hline Pattern \& Process & -.465 & .199 & -.544 & -2.337 & .034 \\
\hline Knowledge Creation & .910 & .300 & .695 & 3.030 & .008 \\
\hline
\end{tabular}

Source: Data processed with SPSS (2021)

Tourism Research Journal, Volume 5 (2), 2021 
The Role of Stakeholders on Successful of Tourism Event

Rendang Journey Culinary Event in Indonesia

Based on the table above, only the knowledge creation variable has a significant effect on the outcomes variable because t-count (3.030) $>$ t-table (2.131) and a significant value of $0.008<0.05$.

Table 6. F-Test

\begin{tabular}{lrrrcc}
\hline & Sum of Squares & df & Mean Square & F & Sig. \\
\hline Regression & 15.304 & 4 & 3.826 & 3.328 & $.039 \mathrm{~b}$ \\
Residual & 17.246 & 15 & 1.150 & & \\
Total & 32.550 & 19 & & & \\
\hline
\end{tabular}

Source: Data processed with SPSS (2021)

Based on the table above, for the simultaneous test, all variables have a significant effect together on the outcomes variable because F-count (3.328) > Ftable (2.96) and significant value $0.039<0.05$.

\section{E. Discussion}

Based on the results of respondents' answers obtained through the distribution of a questionnaire consisting of twelve statements, it can be seen that the policymakers of Rendang Journey's culinary tourism event in Indonesia Strongly Agree with the assessment that the stakeholders of Rendang Journey's culinary tourism event are willing to help and support the culinary tourism event if they are re-organized. An additional indicator that strengthens this activity can be held again, namely the atmosphere and concept of the well-conceived and wellplanned Rendang Journey culinary tourism event in Indonesia (Wijaya et al, 2016).

Knowledge creation has a significant effect on tourism outcomes because creations in rendang tourism can have the opportunity to be developed as a tourist attraction. In their native Minangkabau, local people know many variations of rendang, namely beef rendang, chicken rendang, duck rendang, rendang maco (salted fish), egg rendang, liver rendang, lung rendang, jengkol rendang, fern rendang. , string rendang. The rendang-rendang is made with many variations so that the people who consume it do not get bored which in the end people and stakeholders are interested in visiting to see the Rendang Journey Culinary Event in Indonesia (Nurmufida et al, 2017).

Rendang Journey tourism culinary event stakeholders who stated Agree and Quite Agree were more than half of the assessment indicators given, confirming that the implementation of Rendang Journey culinary tourism event provided new inspiration for the concept of tourism events in Indonesia. The Rendang Journey culinary tourism event is also the largest cultural culinary tourism event ever in Indonesia. The resources owned and the approach taken by the organizers can build a positive image of culinary tourism events. Facilitating the needs of stakeholders for culinary tourism events in Rendang Journey well results

Tourism Research Journal, Volume 5 (2), 2021 
The Role of Stakeholders on Successful of Tourism Event

Rendang Journey Culinary Event in Indonesia

in the satisfaction of stakeholders in these culinary tourism events. The concept of the event as well as a strong and good image makes all assessment indicators positive, in other words, there is no unfavorable assessment of the entire series of concepts of the Rendang Journey culinary tourism event in Indonesia (Wijaya, 2019).

The very good and positive results obtained from the implementation of culinary tourism events are the implementation of -the Rendang Journey culinary event in Indonesia can be categorized as a tourism event. Tourism event is a subfield of education, about studying event management at a destination. Therefore, we need to draw implications for the management of a tourism event well.

The following are some of the opinions and assessments of the respondents of stakeholders on the success of the Rendang Journey culinary tourism event in Indonesia when interviewed: (1) Mrs. Mutia Hatta-Presidential Secretariat of the Republic of Indonesia, building a strong and advanced national character will not be achieved if we do not love our homeland and protect Indonesian assets; (2) Fasli Jalal-Deputy Head of Ministry of National Education, young people are creative and full of fresh and innovative ideas; (3) Mr. Achyaruddin-Director General of Destination Development and MICE Ministry of Tourism and Creative Economy, rendang journey culinary tourism activities in Indonesia do not just end this year, Go International is very easy if all young Indonesians are excited like Rendang Journey culinary tourism activities in Indonesia; (4) William Wongso-Indonesia Culinary Expert, the only culinary seminar I have ever attended that is very concerned about its field and has weight; (5) Vindex Tengker-Executive Chef Dharmawangsa Hotel \& Jury Masterchef, a very professional event for an amateur in creating tourism activities such as Rendang Journey culinary tourism event in Indonesia. Good luck Rendang Journey; (6) Jacky Mussry-Vice President of Markplus Inc, what an amazing event, initiate of Youth and Mostly Women... is showing the power; (7) Yoseptin PratiwiManaging Editor of Femina Magazine, interesting theme and inspiration for young people to love Indonesian culinary. Great hopes for the next Journey of other Indonesian culinary varieties.

\section{E. Conclusion}

The research that has been conducted on the entire series of Rendang Journey culinary tourism events has resulted in a conclusion that makes researchers find accurate factors that can shape success in the implementation of a tourism event, especially in cultural and tourism activities. All assessments and answers obtained from the results of this study received very good and positive scores for the development and continuity of the Rendang Journey culinary tourism event in the future. A very clear and real picture of the opinion of tourism stakeholders Rendang Journey can be accessed through Mrs. UlfiBima's youtube channel. 
The Role of Stakeholders on Successful of Tourism Event

Rendang Journey Culinary Event in Indonesia

The results that have been obtained from this research are very good results to be a benchmark for the continuation of the Rendang Journey culinary tourism event. Rendang Journey's culinary tourism event could be held much better if some of the points that were not of good value from this research became a concern for the organizers. Meanwhile, for further researchers interested in promoting and continuing the Rendang Journey culinary tourism event, it is hoped that: (1) Maintain good and positive values and points from the results of the Rendang Journey culinary tourism event research; (2) Create innovation and innovation to the concept of culinary tourism event Rendang Journey; (3) Improvement of wider cooperative relationships with all stakeholders in culinary tourism event Rendang Journey; (4) Adding and creating high loyalty for all parties involved in the Rendang Journey culinary tourism event.

\section{REFERENCES}

Akgunduz, Y., \& Yesim, C. (2018). Motivations of Event Tourism Participants and Behavioural Intentions. Tourism and Hospitality Management, 24(2): 341 358.

Fenich, G. G. (2012). Meeting, Expositions, Events, and Conventions an introduction to the industry. London: Pearson Education, Inc.

Getz, D., \& Page, S. J. (2015). Progress and prospects for event tourism research. Tourism Management, 52: 593-631.

Giampiccoli, A., \& Saayman, M. (2018). Community-Based Tourism Development Model and Community Participation. African Journal of Hospitality Tourism and Leisure, 7(4): 1-27.

Joseph, O. B. (2015). The Effect of Employees' Motivation on Organizational Performance. Journal of Public Administration and Policy Research, 7(4): 62-75.

Kaiser, M. M. (2019). No Strategic Planning in the Arts A Practical Guide. London: Brandeis University Press New England.

McCartney, G. (2010). Event Management an Asian Perspective. New York: McGrawHill.

Mohajan, H. K. (2017). The Impact of Knowledge Management Models for the Development of Organizations. Journal of Environmental Treatment Techniques, 5(1): 12-33.

Nurmufida, M., Wangrimen, G. H., \& Reinalta, R. (2017). Rendang: The Treasure of Minangkabau. Journal of Ethnic Food, 4(4): 1-12.

Pernecky, T. (2015). Sustainable Leadership in Event Management. Event Management, 19: 109-121.

Rachmawati, E., \& Fountain, J. (2020). Role of External Stakeholders in Tourism Development and Community Empowerment. International Journal of

Tourism Research Journal, Volume 5 (2), 2021 
The Role of Stakeholders on Successful of Tourism Event

Rendang Journey Culinary Event in Indonesia

Applied Sciences in Tourism and Events, 4(1): 25-36.

Sultana, S., \& Parvez, M., \& Khan, R. S. (2020). Perception of Event Management Company Towards Green Event: Evidence From Bangladesh. Academy of Strategic Management Jornal, 19(4): 1-10.

Taormina, R. J., \& Gao, J. H. (2013). Maslow and the Mativation Hierarchy: Measuring Satisfaction of the Needs. The American Journal of Psychology, 126(2): 155-177.

UNWTO (2020). No TitleUNWTO World Tourism Barometer. Retrieved July 25, 2021, from. bttps:/ / doi.org/ https:/ / doi.org/10.18111/wtobarometereng.

Wang, J., \& Aenis, T. (2019). Stakeholder analysis in support of sustainable land management: Experiences from southwest China. Journal of Environmental Management, 243: 1-11.

Wogu, O. E. (2016). Corporate Governance: The Stakeholders Perspective. International Journal of Business and Management Review, 4(4): 45-51.

Wijaya, S. (2019). Indonesian Food Culture Mapping: A Starter Contribution to Promote Indonesian Culinary Tourism. Journal of Ethnic Food, 6(1): 1-10.

Wijaya, S., Morrison, A., Nguyen, T-H., \& King, B. (2016). Exploration of Culinary Tourism in Indonesia: What Do the International Visitors Expect?. Asia Tourism Forum-The 12th Biennial Conference of Hospitality and Tourism Industry in Asia (ATF-16): 0374-0379.

Tourism Research Journal, Volume 5 (2), 2021 